\begin{tabular}{|l|l|l}
\hline & $\begin{array}{l}\text { Proceedings of the } \\
\text { Informing Science }+\end{array}$ & $\begin{array}{l}\text { An Official Publication } \\
\text { of the Informing Science Institute } \\
\text { InformingScience.org }\end{array}$ \\
\hline
\end{tabular}

Online July 7-8, 2020

\title{
A Decision Support System for Pricing AND Minimizing PROdUCT RETURNS
}

\begin{tabular}{lll}
\hline Yahel Giat* & Jerusalem College of Technology, & Jahel@jct.ac.il \\
& Jerusalem, Israel \\
Dan Bouhnik & Jerusalem College of Technology, & bouhnik@jct.ac.il \\
* Corusalem, Israel &
\end{tabular}

\begin{abstract}
Aim/Purpose The first goal is to develop a decision support system for pricing and production amounts for a firm facing high levels of product returns. The second goal is to improve the management of the product returns process.

Background $\quad$ A food importer and manufacturer in Israel with a significant product returns rate.

Methodology A decision support module was added to the plant's information system. The module is based on a supply chain pricing model and uses the sales data to infer future demand's distribution. Ergonomic models were used to improve the design of the returns warehouse and the handling of the returns.

Contribution The decision support system allows to improve the plant's pricing and quantity planning. Consequently, it reduced the number of product returns. The new design of the returns process improves worker's productivity, reduces losses and results in safer outcomes.

Findings The results show the promise of incorporating pricing supply chain models into informing systems to achieve a practical business goal.

Recommendations This work can be replicated for different suppliers, manufacturers and retailfor Practitioners ers that suffer from product returns. They will benefit from the reduction in returns, as well as the decrease in the losses associated with these returns.
\end{abstract}

Accepted by executive review by Editor Michael Jones | Received: December 28, 2019 | Revised: January 27, 2020 | Accepted: January 28, 2020.

Cite as: Giat, Y., \& Bouhnik, D. (2020). A decision support system for pricing and minimizing product returns. In M. Jones (Ed.), Proceedings of InSITE 2020: Informing Science and Information Technology Education Conference, pp 4759. Informing Science Institute. https://doi.org/10.28945/4522

(CC BY-NC 4.0) This article is licensed to you under a Creative Commons Attribution-NonCommercial 4.0 International License. When you copy and redistribute this paper in full or in part, you need to provide proper attribution to it to ensure that others can later locate this work (and to ensure that others do not accuse you of plagiarism). You may (and we encourage you to) adapt, remix, transform, and build upon the material for any non-commercial purposes. This license does not permit you to use this material for commercial purposes. 
Recommendations It is worthwhile to research whether decision support systems can be applied for Researchers to other aspects of the organizations' operations.

Impact on Society Product returns is a lose-lose situation for producers, retailers and customers. Moreover, mismanagement of these returns is harmful for the environment and may result in the case of foods, in health hazards. Reducing returns and improving the handling improves sustainability and is beneficial for society.

Future Research The DSS's underlying pricing model assumes a specific business setting. This can be extended using other pricing models and applying them in a similar fashion to the current application.

Keywords supply chain, pricing model, Israel, food industry, product returns, decision support system, ergonomics

\section{INTRODUCTION}

Information systems have many important roles in complex business environments, ranging from simple information-keeping to complex analysis and decision making. In this paper, we describe an in-house upgrade that transformed a basic marketing and sales information system into a decision support system (DSS) for the control of product returns by determining the sales quantities and prices and the onsite warehouse management of these returns.

This system was developed in a midsized food manufacturer and importer in Israel (henceforward, the manufacturer). The manufacturer imports, produces and markets almost a thousand different product types ranging from legumes, grains, spices, dry fruits, candies and packaged snacks. Its annual sales are near 150 million NIS (approximately 45 million USD) and operations are conducted in a single facility. Distribution to the retailers is generally done by the manufacturer's own fleet of trucks. Many of its items are seasonal and correlate with the Jewish holidays and therefore workload and sales, fluctuate throughout the year. The manufacturer is unique in that it is very popular among the religious population in Israel who demand that all its products are Kosher-certified (see, Giat, 2018 for considerations about certification). The religious population in Israel has a small per capita purchasing power compared with other population segments and therefore, retailers in this market face fierce competition with small profit margins. Returns are a very costly component in this market (Reagan, 2016) and, therefore, minimizing these costs is of outmost importance to the manufacturers and the retailers alike.

For our manufacturer, the main source of returns is the manufacturer's policy to ship the retailer any amount that the retailer demands even though it is quite likely that the retailer will be unable to sell it. As part of the deal the manufacturer guarantees the retailer that it will accept any returned amount. The producer's reasoning behind this sales scheme is to gain as much presence in the retailer's shelf space in order to attract as much market share as possible.

For many types of products, however, there is no such advantage to the manufacturer. These are mainly products that only the manufacturer produces and, therefore, does not face competition from other manufacturers. Since, however, the agreement with the retailer about accepting back any amount that it wishes to return is still binding, the only way to reduce the retailer's order size is by employing pricing schemes that will cause the retailer to order the optimal amount. The first goal of this study is to implement such a scheme in the manufacturer's information system.

The second goal of this study is to redesign the facility and the operations of the returns process. Regrettably, the current managing and handling of the returns is inadequate. This mismanagement results in monetary losses not to mention the potential for health hazards if spoiled foods are returned to the market. We use ergonomic methods to redesign the facility in which returns are received and handled and implement procedures on how they are to be handled. 
Giat \& Bouhnik

\section{LITERATURE REVIEW}

We use a supply chain coordination model that is described in Cachon and Lariviere (2005) to calculate the optimal prices and quantities. They show that the competition between the supplier (or producer or manufacturer) and the retailer leads to losses to all the parties involved including the customers. They explain that to eliminate these losses and achieve the optimal solution the supply chain must be coordinated. They analyze a few models that achieve this goal. The two main schemes are revenue sharing and buyback.

The revenue sharing scheme is when the retailer and the supplier contract to share revenues from customers and was famously applied by Hollywood studios and the video chain Blockbuster (see Warren \& Peers, 2002). Recent research in these types of contracts includes Hu and Feng (2017), Hou et al. (2017), Gamchi and Torabi (2018), and Gerchak and Schwartz (2018).

Buyback contracts dictate that the supplier agrees to purchase back from the retailer some or all the quantity that the retailer was unable to sell, thus mitigating the classical "newsvendor" problem (Arrow et al., 1951). Recent research about buyback supply chain coordination models include Adhikari (2016), Duc et al. (2018), and Sainathan and Groenevelt (2019).

One of the variants of the buyback schemes is the supplier agreeing to buy back at the full wholesale cost part or all of the unsold items. The agreements are prevalent in the retail business and as a result many suppliers deal with a large returns volume. Rogers et al. (2002) presents an overview of the returns' management process and Mollenkopf et al. (2007) provide a supply chain logistics perspective to this managerial challenge. The returns problem is an important component of the field of reverse logistics (see Dekker et al., 2013, and Srivastava \& Srivastava, 2006) and the more recent term "closed-loop supply chain", which also deals with broader issues such as waste management, sustainability, end-of-life, cannibalization (e.g., Dreyfuss et al., 2018) and repair (e.g., Dreyfuss \& Giat, 2017, and Dreyfuss \& Giat, 2018a). Recent reviews of the field are Govindan, Soleimani, and Kannan (2015), Govindan and Soleimani (2017), and Wang et al. (2017).

The supply coordination models assume there is information sharing between the supplier and the retailer. In fact, this information sharing is essential to mitigate many types of supply chain disruptions. For example, the "bull-whip effect" (also known as the Forrester effect), is a phenomenon in which small fluctuation of demands tend to amplify as they move up the supply chains (Forrester, 1961; Lee et al., 2004). Information sharing is key to mitigating the bull-whip effect. A famous example of this is Grean and Shaw's (2002) description of the successful relationship between Proctor \& Gamble and Wal-Mart. Information coordination and sharing between these corporates was key to their successful relationship and to the elimination of the bull-whip effect.

Information systems for business management are known as ERP (Enterprise Resource Planning) systems and cover the whole scope of the business operations (see Jacobs, 2007; Soh et al., 2000). The disadvantage of "off the shelf" ERP systems (by vendors like SAP, Oracle, Microsoft and others) is that they may not address the specific idiosyncratic needs of the business. Moreover, businesses' needs are not only complex but rapidly changing requiring numerous updates and special software patches to address these complexities and changes. Consequently, many businesses opt to develop their ERP system in house so that they are tailored to their specific needs and requirements (see a similar approach with government websites in Bouhnik et al., 2013). Another advantage of inhouse development is the ability to install investments, thus expending the costs only when it is profitable to do so (Giat, 2013).

Another advantage of developing in-house systems is that the user of these systems knows best what tasks must be achieved. This is crucial for any successful informing system, as Cohen (1999) points out that "the driving force behind the creation of informing environments and delivery systems is that a task needs to be accomplished" (page 217). In the case of a for-profit business enterprise the 
required tasks are very complex and therefore require sophisticated informing systems. See more on the relationship between task complexity and informing systems in Gill (2006).

In our particular case the informing system is required to help decide prices and quantities. As such, it also serves as a decision support system (DSS). There are various ways to model such systems (e.g., Aggarwal, 2001) and they are used in a wide array of applications (e.g., Cornforth et al., 2014; Dreyfuss \& Giat, 2018b; Mbugua \& Suksa-ngiam, 2018).

To organize the returns warehouse in the factory, we employ methods from the field of ergonomics. This field of research combines human factors with operations, engineering and design and is overviewed in many publications, including Sanders and McCormick (1993), McCauley-Bush (2011), Salvendy (2012) and Stanton et al. (2017). Of interest to this paper is Wilkinson and Aerodrome (1992) who develops a design methodology that uses an analysis of operational procedures and requirements for the design of a fighter jet cockpit. Although their model was developed in the military aviation context, it is in fact generic and can be applied to other domains. Badihi and Trabelsi (2016) extend Wilkinson's and Aerodrome's model in their model for an ergonomic design and organization of operations. Their model details many aspects of the mission and the user profiles and then uses this information for a detailed design of the workplace physical and operational structure.

\section{THE INFORMATION SYSTEM}

The information system contains two modules:

1. A database that stores all the sales and returns data.

2. A decision support system that evaluates the sales data and makes specific recommendations.

Sales and return data are the information generated along the sales-returns process. This process comprises a number of steps:

1. Determining the amounts and prices through negotiation with the retailer.

2. Distribution to the retailer. This is done by the manufacturer's trucking fleet.

3. The retailer gives the manufacturer's driver the returns

4. Returns' management within the plant. This may result in discarding, repackaging and/or reselling,

\section{DATABASE}

The information generated during the sales-returns process is recorded in the database. It serves many purposes such as for general accounting, determining performance of the sales marketing/sales agents and so forth.

The database includes two main modules:

Sales module - Includes screens updating the sales of the different products. It records the salesperson who made the deal, the retailer, amount, prices and other relevant information.

Return's module - Includes information regarding the returns. Who initiated the return, reason for return, retailer details, driver that delivered it back, the person in charge in the returns facility in the plant, what corrective actions were taken, was it resold, and so forth.

As with any database it is imperative that the user interface is as friendly as possible. This is especially true in this particular project in which the users speak different languages (only part of the employees are native Hebrew speakers, whereas the others are either Arabic speakers or Russian speakers).

Moreover, the computer skills of the prospective users are varied. Many of the employees (especially 
the drivers and those receiving and handling returns in the facility) have a very basic level of education (some did not even graduate high school) and their digital literacy may be minimal.

The importance of information that is stored in the database goes beyond its accounting value and is used as a critical source of input for the DSS module. It provides the data needed to determine the consumer demand, which is necessary for the supply chain pricing model that determines the recommeneded prices and amounts. To show how this is done we first describe the pricing model.

\section{THE PRICING MODEL}

At the heart of the DSS is the supply chain model described in Cachon and Lariviere (2005). This is a simplified supply chain that comprises two stages; the supplier and the retailer. Each of the stages is monopolistic (i.e., single supplier and single retailer). The supplier sells to the retailer at the wholesale price, denoted by $w$, and the retailer sells to customers at the customer price, denoted by $p$. Demand is stochastic and is assumed to be $D(D$ is a random variable) with a known distribution. See Figure 1 for a schematic overview of the supply chain. The supplier has a marginal production (or import) cost, $c_{s}$. In our plant, these costs could be manufacturing costs (for items manufactured in the plant) or purchasing costs (for imported items) in addition to the packaging, shipping and handling costs. In the more general case, costs need not be linear with the amount of production (or import). However, after consulting with the operations and finance staff it was agreed that a constant unit cost is a good approximate for the true costs. The following derivations are basic economic theory and are provided to introduce readers that are not from the field to the basic concepts.

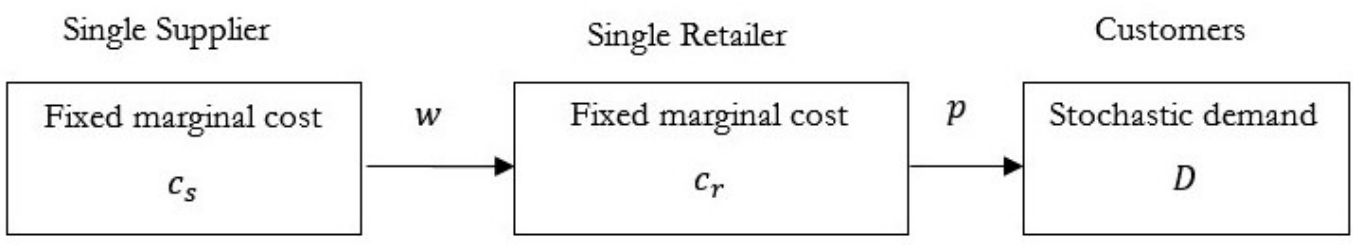

Figure 1: Supply chain structure

The plant and the retailer are separate entities and are (currently) not coordinated, therefore, each party's goal is to maximize its own profits. More precisely, they are assumed to be risk-neutral and therefore their goal is to maximize their expected profits. Their actual decisions, however, are different. Whereas the supplier determines the wholesale cost, the retailer responds with ordering the amount that will maximize its expected profits' given by

$$
E\left[\pi_{r}(q)\right]=E\left[p \operatorname{Min}\{q, D\}-w q-c_{r} q\right]
$$

In the profit function, the revenue is the customer price, $p$, multiplied by the amount sold, which is the smaller of the quantity that the retailer ordered, $q$, and the realized demand, $D$.

Anticipating this, the supplier will carefully set the wholesale price and the amount $(w, q)$ to maximize its own profit, given by

$$
\pi_{s}=w q-c_{s}(q)
$$

To derive equilibrium outcome, we begin with analyzing the retailer's best response (i.e., the quantity that maximizes its profit) to the wholesale price, $w$.

$$
\begin{aligned}
& \max _{q} E\left[\pi_{r}(q)\right]=E\left[p \operatorname{Min}\{q, D\}-w q-c_{r} q\right] \\
& =p E[\operatorname{Min}\{q, D\}]-\left(w+c_{r}\right) q \\
& =p\left[\int_{-\infty}^{q} f(D) D d D+\int_{q}^{+\infty} q f(D) d D\right]-\left(w+c_{r}\right) q
\end{aligned}
$$


If, for example, we assume that demand is distributed uniformly between $a$ and $b$ (i.e., $D \sim U(a, b)$ ), then $E[\operatorname{Min}\{q, D\}]=\frac{1}{b-a}\left(-0.5 q^{2}+b q-0.5 a^{2}\right)$, and the retailers optimization problem is

$$
\max _{q} \frac{p}{b-a}\left(-0.5 q^{2}+b q\right)-\left(w+c_{r}\right) q .
$$

The first order optimization condition is

$$
\frac{-p}{b-a} q+\frac{b p}{b-a}-w-c_{r}=0
$$

That is, the retailer's best response is $q=b-\frac{\left(w+c_{r}\right)(b-a)}{p}$. From the supplier's perspective, the retailer's demand follows

$$
w=\frac{p(b-q)}{b-a}-c_{r}
$$

Anticipating this response, the supplier optimization problem is

$$
\max _{q} \pi_{s}=w q-c_{s} q=\left(\frac{p(b-q)}{b-a}-c_{r}\right) q-c_{s} q
$$

and therefore, the equilibrium quantity that solves the supplier's problem is: $q=\frac{b}{2}-\frac{\left(c_{r}+c_{s}\right)(b-a)}{2 p}$

In the above we assume internal solutions (which obviously depend on the parameter values). The problem with this equilibrium solution is that it is suboptimal for the supply chain as a whole. One can easily show, that to optimize the total (retailer and supplier) profits then the optimal quantity is $q_{M}=b-\frac{\left(c_{r}+c_{S}\right)(b-a)}{p}$, which is double the equilibrium quantity of the uncoordinated supply chain. Assigning this to the profits reveals that the total supply chain profits are $4 / 3$ times higher than the sum of the profits of the retailer and supplier in the uncoordinated supply chain. Therefore, if the supplier and the retailer could agree to cooperate optimally, they could not only each earn more profits, but also provide more benefit to the customers, which will purchase more at a lower cost.

One model that coordinates the supply chain with this goal in mind is the buy-back model in which the supplier agrees to purchase back all the unsold items for price $B$. Without the coordination, the retailer bears all the risk (that demand will fall short and she will be unable to sell all her order) and therefore the retailer is inclined to purchase suboptimal amounts. Since risk is non-linear, when the supplier shares part of the risk with the retailer, the total negative effect of risk is lower, allowing both parties to gain.

For this model to obtain optimal coordination the relationship between the buyback price and the wholesale price must follow $w=c_{s}+B\left(1-\left(c_{r}+c_{s}\right) / p\right)$. The specific values of $B$ and $w$ determined how profits are divided between the retailer and the supplier.

We note that the equations above are for the uniform demand case. Similar techniques are employed for other distributions. We refer the interested reader to Cachon and Lariviere (2005) for more details about the buyback contract model as well as other models for supply chain coordination.

\section{DESCISION SUPPORT SYSTEM}

The purpose of the DSS module is to assist managers with the task of making pricing decisions and deciding on production and import amounts. To do so it uses sales data from the IS's database module as input for the pricing model that was described in the previous section as follows. The information's support system's general structure is given in Figure 2. 
Giat \& Bouhnik

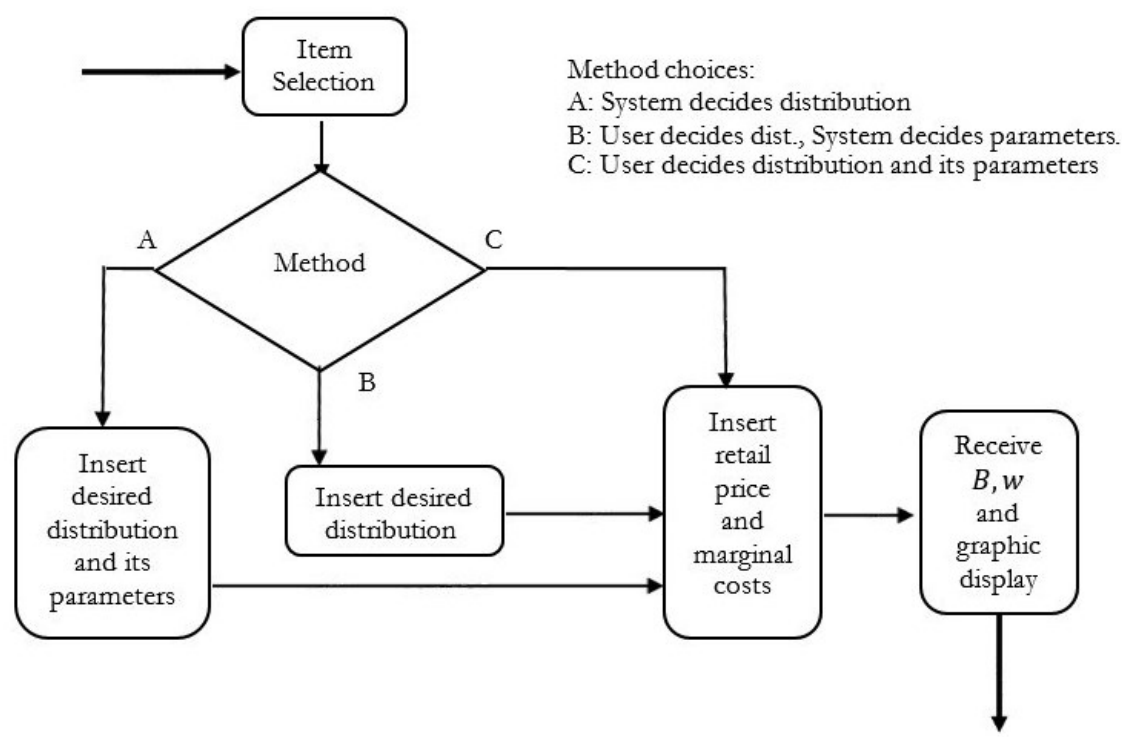

Figure 2: DSS pricing schema

For example, a few months before the holiday seasons, managers negotiate with major retailers (this is frequently done with the store's procurement officer, even with stores that are part of a major chain) the amount they will ship to them as well as the wholesale price.

The pricing model's output crucially depends on the customer demand function (see in detail in Section 'The Pricing Model'). Therefore, to determine the optimal price and amount according to the economic model it is necessary to determine the expected demand distribution. The system offers three ways to do this.

1. The system determines the distribution based on past sales.

2. The user sets the general distribution and the system find the distribution's best parameters based on past sales. For example, the user may decide that demand is Normally distributed whereas the mean and standard deviation are determined by the system.

3. The user determines the distribution in full. For example, the user could set the distribution as Normal and set the mean and standard deviation.

In the second and third schemes, the user may choose any one of a given menu of distributions. The basic menu includes the Uniform, Normal and Exponential distributions. When needed, adding other distributions can be done very easily by the system's maintenance team.

In the second scheme, the system determines the distribution's parameters by matching the first moments (as many as necessary). For example, if a Normal distribution is desired, then the system uses past data to compute the average past sales and its variance. These are then used as the parameters of the distribution.

In the third scheme the user determines both the distribution and its parameters. This can be used when there is insufficient historical sales data or when the user feels that past sales are irrelevant to determining future sales.

Once the demand distribution has been determined the system provides the recommended prices.

\section{RETURNS MANAGEMENT}

The purpose of the DSS is to improve the returns process. In our examination of the factory's returns handling we found four main problems in the management of the returns: 
1. There is deficient documentation and classification of the returned item when taken from the retailer.

2. Responsibilities are not defined clearly. This lack of responsibility frequently leads to things slipping through the cracks instead of being handled efficiently.

3. Frequently, the sales agents do not fill the returns reports and therefore returns may arrive to the returns warehouse without any additional information. As a result, the returns' department employees struggle to determine the problem and what exactly should be done with the returned items.

4. Many times, the distribution truck drivers do not verify that all the items listed in the returns form are present in the returns' pallet by the retailer. As a result, there is a mismatch between the listed inventory and the actual inventory that arrives to the returns warehouse.

5. The returns warehouse itself was unorganized and disheveled. Boxes continuously arrived and were piled in a very unorderly manner. Warehouse employees randomly opened boxes and started sorting its contents to determine what to do with each item. They then created new piles of items according the items' designation. Examples for these designations are discard, repackage, relabel, reprocess and "to be determined".

To improve the returns management, a "Returns Management" module was designed and added to the information system. In addition, the returns operations were reformulated to all the workers along the supply chain and a new physical layout of the warehouse was designed.

\section{RETURNS WAREHOUSE DESIGN}

As explained above, the current state of the warehouse is a great source of inefficiencies. For its redesign we first describe the mission and user profiles.

\section{MISSION PROFILE}

The mission is defined as: Treating returns beginning with their arrival at the plant, the determination of what actions need to be done and the execution of these actions.

Scope: From the moment the truck carrying the returns enters the plant's gates until the treatment of each of the items has been completed.

Mission activities:

1. Truck arrival and the unloading of the merchandise.

2. Verifying actual amounts match the amounts listed on the returns form.

3. Bringing the returns to the warehouse and classifying them as either for reuse or for disposal.

4. Handling any product as determined in the previous step.

Activities and expected results:

Each activity (and its corresponding expected result) is graded by a criticality index $(\mathrm{CI})$, with $\mathrm{CI}=5$ indicating very critical and $\mathrm{CI}=1$ indicating least critical).

1. Activity 1: All the products that the retailer wants to return have indeed arrived at the plant. $\mathrm{CI}=5$. Without the completion of this activity the other activities could not be executed.

2. Activity 2: The returns are unloaded off the truck into the warehouse. CI $=5$. Without the completion of this activity the other activities could not be executed.

3. Activity 3: The store's declaration of returns matches the actual returns. CI=3. It prevents fraud and losses but does not prevent other activities to be executed. 
4. Activity 4: Each product fits into one of the classification categories. $\mathrm{CI}=4$. Items that are unfit for consumption must not return to the marketing chain.

5. Activity 5: Each product was handled according to its category. CI=5. Saves money and prevents health hazards.

Possible failures:

1. Leaving the returns on the ramps instead of immediately bringing them into the warehouse.

2. Misclassification of the returns.

3. Products wait for too long until they are handled.

Health and safety:

1. Products left outside for too long may degrade (long-term effects).

2. Classification of unfit products as fit for consumption (immediate effect).

3. Health hazard for employees working in unfit conditions (sitting on the floor or on unstable boxes).

Activities' order:

The activities must be executed consecutively (from Activity 1 to 5). Each activity requires that the previous activity has been completed and therefore there is no flexibility in their order of execution.

Other consideration:

Weather: Rainy days in the winter and hot days in the summer are especially harmful to the returns.

Seasonality: Following the holidays there is a very large volume of returns that requires more than the usual operation hours.

\section{USER PROFILE}

Psychophysiological skills: Most of the activities do not require any special skills. Incoming packages may be heavy and surpass $30 \mathrm{~kg}$. Fine motor skills are required for handling smaller items.

Mental skills: The activities do not require advanced memory ability or information processing. The main mental requirement is the ability to classify produce using one's own judgment.

Professionalism: The activities require professionalism. Errors in judgment or in execution can result with health hazards and losses.

Language skills: Most of the communication is between the employees of the return's room and with their supervisors. Most employees converse in Arabic whereas many of the managers in Hebrew. Therefore, basic knowledge of each of the languages in required.

Interpersonal skills: The return's warehouse employees stay together throughout the day and have workers come over from other departments to take produce. A calm and friendly atmosphere is needed for improving efficiency.

\section{MODELLING THE RETURNS'ROOM}

The analysis of the mission and user profiles reveals that the current state of the returns' room does not allow for an optimal treatment of returns. Ergonomically, it is ill designed and therefore does not permit reasonable execution of the required activities. In its current state, employees sit on the floor or on boxes with the merchandise accumulating into disorganized piles. The employees are working the merchandise on the floor without presorting of any kind. Figure 3 illustrates the current state of affairs in the room. 


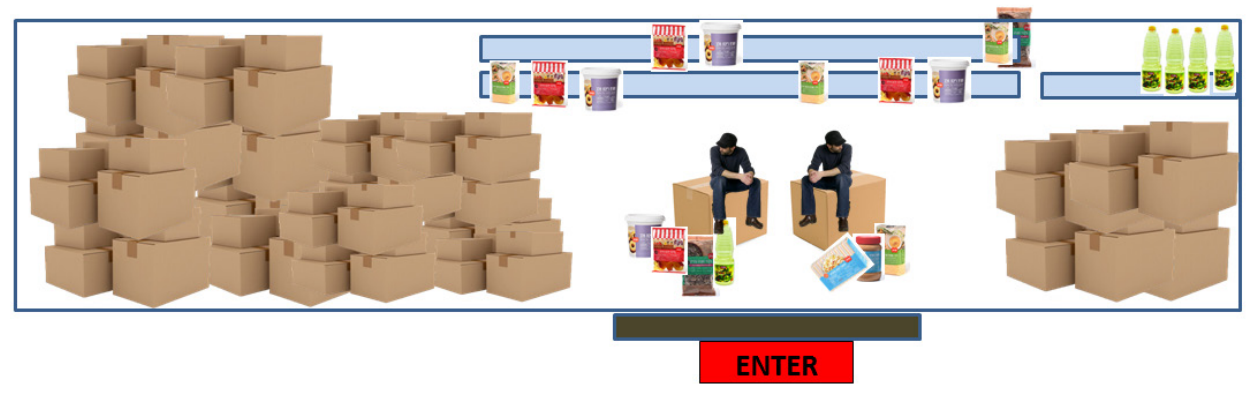

Figure 3: A schema of the returns' warehouse current state

For the redesign, we used the software Sketchup. It supports three-dimension design and is used in many design, architecture and engineering applications. We took the room's dimensions as given and used ergonomic theory to redesign the room to support a proper reception of returns, their sorting and their storage. It also considers human factors such as seating, lifting etc. In Figure 4 we plot the room's new design.

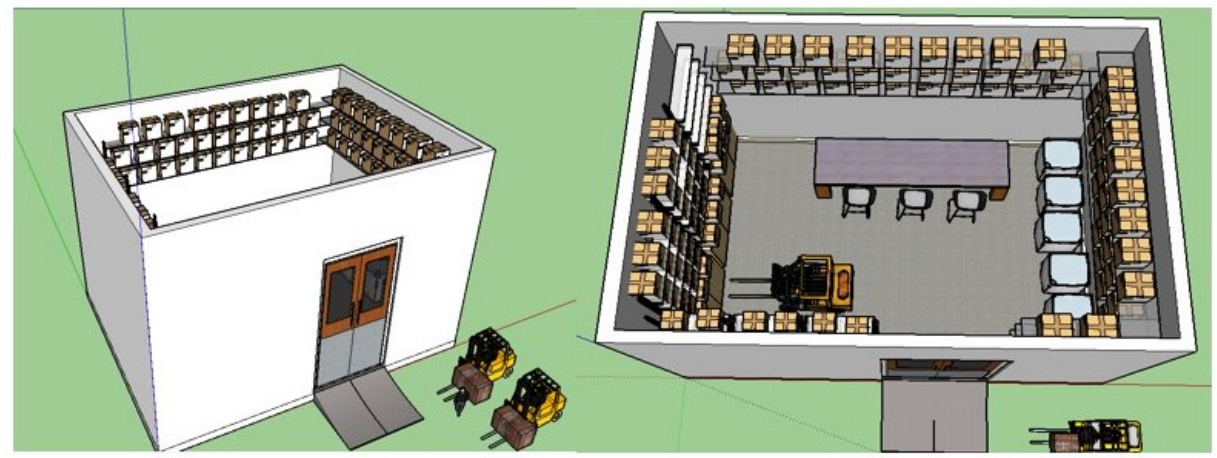

Figure 4: A schema of the returns' warehouse new design

Shelves were placed along the entire length of the room to contain the products that are to be repackaged or resold. A table was brought into the room so that sorting or repackaging can be done while seated. Sufficient space was left to allow a forklift to enter the room and be able to maneuver in it safely. The boxes on the shelves are to be managed under a first-in-first-out (FIFO) policy. This will ensure that products are not overlooked. Large containers were placed in a row. These are to be filled according to the destination of the sorted products, disposal or factory departments (for repackaging). These are to be emptied at the end of each workday, thus completing the treatment of the returns.

\section{RESULTS AND CONCLUSIONS}

This study improves the management of returns by developing a decision support information system and by ergonomic-based design of the facility that handles the returns. In the first part, an inhouse sales information system was enhanced to support managers and sales agents in how they set prices. This information system uses sales data that was already available in the system and processes it to determine the optimal price to charge the retailers. As a byproduct of the maximization of profits, the result is that the retailers will purchase smaller quantities and therefore the returns are minimized as well. As a complement to the DSS, we improved the management and handling of the returns themselves. Whereas previously the reports were never verified, in the new setting returns are recorded and checked against the actual product arrival. Furthermore, the redesign of the warehouse increases operations' efficiency and reduces the risk that products that are unfit for consumption are resold. 
The pricing model at the heart of the DSS assumes that the retailer and the supplier of the item are monopoles. This assumption is reasonable for only a subset of the retailer's products and for a subset of the retailers, those that do not face competition in their specific location from other large retailers. As a first step of testing the DSS, we selected somewhat less than a hundred (product, retailer) candidates for the experiment. Next, we assigned values to the cost variables. In most cases these data were readily available at the plant, in others we asked the operation's staff to provide us with their estimations. Historical sales data stored in the database was used to derive past demand for each of the products. Some of the products have less than three years of sales information and for these we used the marketing staff to estimate the demand's distribution.

\section{REFERENCES}

Adhikari, A. (2016). Coordinating a dyadic fashion apparel supply chain using a specially designed buyback revenue sharing contract. SSRN. https://doi.org/10.2139/ssrn.2799483

Aggarwal, A. K. (2001). A taxonomy of sequential decision support systems. Proceedings of the Informing Science Conference. https://doi.org/10.28945/2382

Arrow, K. J., Harris, T., \& Marschak, J. (1951). Optimal inventory policy. Econometrica: Journal of the Econometric Society, 19(3), 250-272. https://doi.org/10.2307/1906813

Badihi, Y., \& Trabelsi, M. (2016). Ergonomics for industrial engineers. Lecture Notes. Jerusalem, Israel: Jerusalem College of Technology.

Bouhnik D., Giat, Y., \& Nitzan, G. (2013). The usability of Israel's government websites. International Journal of E-Business Development, 3(4), 188-198. https://www.deepdyve.com/lp/world-academic-publishing-co/theusability-of-israel-s-government-websites-OI0IVH0bYK

Cachon, G. P., \& Lariviere, M. A. (2005). Supply chain coordination with revenue-sharing contracts: Strengths and limitations. Management Science, 51(1), 30-44. https://doi.org/10.1287/mnsc.1040.0215

Cohen, E. (1999). Reconceptualizing information systems as a field of the transdiscipline informing science: From ugly duckling to swan. Journal of Computing and Information Technology, 7(3), 213-219. https://hrcak.srce.hr/file/221129

Cornforth, D. J., Robinson, D., Spence, I., \& Jelinek, H. (2014). Heart rate recovery in decision support for high performance athlete training schedules. Interdisciplinary Journal of Information, Knowledge, and Management, 9, 193-207. https://doi.org/10.28945/2085

Dekker, R., Fleischmann, M., Inderfurth, K., \& van Wassenhove, L. N. (Eds.). (2013). Reverse logistics: Quantitative models for closed-loop supply chains. Springer. https://doi.org/10.1007/978-3-540-24803-3

Dreyfuss, M., \& Giat, Y. (2017). Optimal spares allocation to an exchangeable-item repair system with tolerable wait. European Journal of Operational Research, 261(2), 584-594. https://doi.org/10.1016/j.ejor.2017.02.031

Dreyfuss, M., \& Giat, Y. (2018a). Optimal allocation of spares to maximize the window fill rate in a two-echelon exchangeable-item repair system. European Journal of Operational Research, 270, 1053-1062. https://doi.org/10.1016/i.ejor.2018.05.011

Dreyfuss, M., \& Giat, Y. (2018b). Decision support information system for urban lighting. Issues in Informing Science \& Information Technology, 15, 109. https://doi.org/10.28945/3995

Dreyfuss, M., Giat, Y., \& Stulman, A. (2018). An analytical approach to determine the window fill rate in a repair shop with cannibalization. Computers \& Operations Research, 98, 13-23. https://doi.org/10.1016/j.cor.2018.05.018

Duc, T. T. H., Loi, N. T., \& Buddhakulsomsiri, J. (2018). Buyback contract in a risk-averse supply chain with a return policy and price dependent demand. International Journal of Logistics Systems and Management, 30(3), 298329. https://doi.org/10.1504/IJLSM.2018.092612

Forrester, J. (1961). Industrial dynamics. MIT Press, and John Wiley \& Sons. Inc. 
Gamchi, N. S., \& Torabi, S. A. (2018). Supply chain coordination under revenue-sharing contract with valueadded services considering risk-attitude of the customers. International Journal of Services and Operations Management, 29(4), 507-526. https://doi.org/10.1504/IJSOM.2018.090455

Gerchak, Y., \& Schwartz, G. (2018). Supply chain coordination with multiple retailers and nonlinear production costs. International Journal of Operational Research, 32(2), 251-265. https://doi.org/10.1504/IJOR.2018.092016

Giat, Y. (2018). A location model for boycotting with an application to kosher certification. European Journal of Operational Research, 273(3), 1109-1118. https://doi.org/10.1016/j.ejor.2018.09.001

Giat, Y. (2013). The effects of output growth on preventive investment policy. American Journal of Operations Research, 3(06), 474. https://doi.org/10.4236/ajor.2013.36046

Gill, T. G., \& Hicks, R. C. (2006). Task complexity and informing science: A synthesis. Informing Science: The International Journal of an Emerging Transdiscipline, 9, 1-30. https://doi.org/10.28945/469

Govindan, K., \& Soleimani, H. (2017). A review of reverse logistics and closed-loop supply chains: A Journal of Cleaner Production focus. Journal of Cleaner Production, 142(Part 1), 371-384. https://doi.org/10.1016/j.jclepro.2016.03.126

Govindan, K., Soleimani, H., \& Kannan, D. (2015). Reverse logistics and closed-loop supply chain: A comprehensive review to explore the future. European Journal of Operational Research, 240(3), 603-626. https://doi.org/10.1016/j.ejor.2014.07.012

Grean, M., \& Shaw, M. J. (2002). Supply-chain partnership between P\&G and Wal-Mart. In M. J. Shaw (Ed.), E-business management (pp. 155-171). Boston, MA: Springer. https://doi.org/10.1007/0-306-47548-0 8

Hou, Y., Wei, F., Li, S. X., Huang, Z., \& Ashley, A. (2017). Coordination and performance analysis for a threeechelon supply chain with a revenue sharing contract. International Journal of Production Research, 55(1), 202227. https://doi.org/10.1080/00207543.2016.1201601

Hu, B., \& Feng, Y. (2017). Optimization and coordination of supply chain with revenue sharing contracts and service requirement under supply and demand uncertainty. International Journal of Production Economics, 183(Part A), 185-193. https://doi.org/10.1016/j.ijpe.2016.11.002

Jacobs, F. R. (2007). Enterprise resource planning (ERP) - A brief history. Journal of Operations Management, 25(2), 357-363. https://doi.org/10.1016/j.jom.2006.11.005

Lee, H. L., Padmanabhan, V., \& Whang, S. (2004). Information distortion in a supply chain: The bullwhip effect. Management Science, 50(12_supplement), 1875-1886. https://doi.org/10.1287/mnsc.1040.0266

Mbugua, J. K., \& Suksa-ngiam, W. (2018). Predicting suitable areas for growing cassava using remote sensing and machine learning techniques: A study in Nakhon-Phanom Thailand. Issues in Informing Science and Information Technology, 15, 043-056. https://doi.org/10.28945/4024

McCauley-Bush, P. (2011). Ergonomics: Foundational principles, applications, and technologies. CRC Press. https://doi.org/10.1201/b11552

Mollenkopf, D., Russo, I., \& Frankel, R. (2007). The returns management process in supply chain strategy. International Journal of Physical Distribution \& Logistics Management, 37(7), 568-592. https://doi.org/10.1108/09600030710776482

Reagan, C. (2016, December 16). A $\$ 260$ billion 'ticking time bomb’: The costly business of retail returns. CNBC. https://www.cnbc.com/2016/12/16/a-260-billion-ticking-time-bomb-the-costly-business-of-retail-returns.html

Rogers, D. S., Lambert, D. M., Croxton, K. L., \& García-Dastugue, S. J. (2002). The returns management process. The International Journal of Logistics Management, 13(2), 1-18. https://doi.org/10.1108/09574090210806397

Sainathan, A., \& Groenevelt, H. (2019). Vendor managed inventory contracts - Coordinating the supply chain while looking from the vendor's perspective. European Journal of Operational Research, 272(1), 249-260. https://doi.org/10.1016/j.ejor.2018.06.028 
Salvendy, G. (Ed.). (2012). Handbook of buman factors and ergonomics. John Wiley \& Sons. https://doi.org/10.1002/9781118131350

Sanders, M. S., \& McCormick, E. J. (1993). Human factors in engineering and design (7th ed.). McGraw-Hill.

Soh, C., Kien, S. S., \& Tay-Yap, J. (2000). Enterprise resource planning: Cultural fits and misfits: Is ERP a universal solution? Communications of the ACM, 43(4), 47-51. https://doi.org/10.1145/332051.332070

Srivastava, S. K., \& Srivastava, R. K. (2006). Managing product returns for reverse logistics. International Journal of Physical Distribution \& Logistics Management, 36(7), 524-546. https://doi.org/10.1108/09600030610684962

Stanton, N. A., Salmon, P. M., Rafferty, L. A., Walker, G. H., Baber, C., \& Jenkins, D. P. (2017). Human factors methods: A practical guide for engineering and design. London: CRC Press. https://doi.org/10.4324/9781351156325

Wang, J. J., Chen, H., Rogers, D. S., Ellram, L. M., \& Grawe, S. J. (2017). A bibliometric analysis of reverse logistics research (1992-2015) and opportunities for future research. International Journal of Physical Distribution \& Logistics Management, 47(8), 666-687. https://doi.org/10.1108/IJPDLM-10-2016-0299

Warren, A., \& Peers, M. (2002, June 13). Video retailers have day in court - Plaintiffs say supply deals between Blockbuster Inc. and studios violate laws. Wall Street Journal, 13, B10. https://www.wsi.com/articles/SB102390590866535200

Wilkinson, P. R., \& Aerodrome, W. (1992). The integration of advanced cockpit and systems design. Advisory Group for Aerospace Research \& Development (AGARD) Avionics Panel Symposium (pp. 235-242). Madrid, Spain: North Atlantic Treaty Organization (NATO). https://apps.dtic.mil/dtic/tr/fulltext/u2/a258048.pdf\#page=235

\section{BIOGRAPHIES}

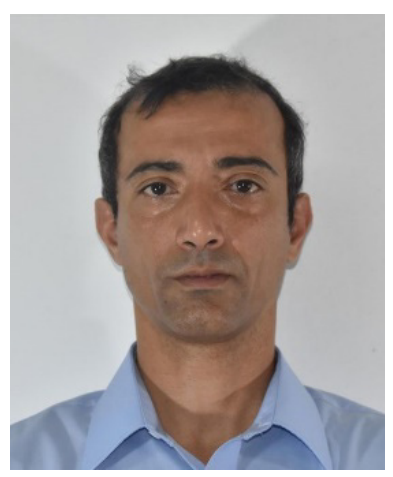

Dr. Yahel Giat is a tenured faculty member in the Department of Industrial Engineering and Management in the Jerusalem College of Technology. He holds a Ph.D. and an MSc. in Industrial Engineering from the Georgia Institute of Technology, an MSc. in Economics, a B.Sc. in Electrical Engineering and B.A. in Computer Sciences from the Israel Institute of Technology.

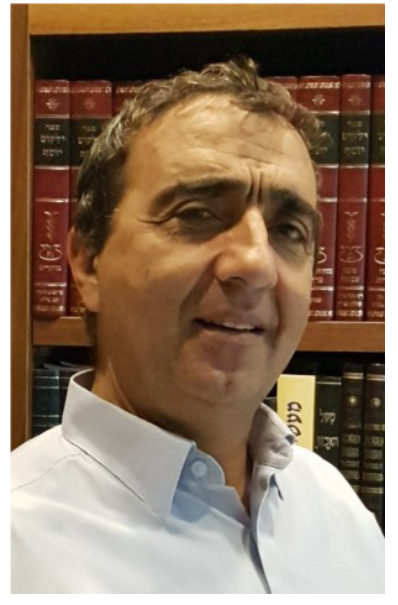

Prof. Dan Bouhnik is the head of the Computer Science department in the Jerusalem College of Technology (JCT) in Israel. He is the author of several books used for teaching advanced computer sciences and his professional interests include virtual learning and its effect on the thinking process, information needs of special groups as well as the infusion of new technologies in the learning environment. 